\title{
Variation of Growth with Latitude in Two Species of Rockfish (Sebastes pinniger and S. diploproa) from the Northeast Pacific Ocean
}

\author{
G. W. Boehlert* and R. F. Kappenman \\ Northwest and Alaska Fisheries Center, 2725 Montlake Boulevard East, Seattle, Washington 98112, USA
}

\begin{abstract}
Growth of two Sebastes species was measured as fish length versus age, determined from otoliths. S. pinniger and $S$ diploproa were collected extensively over their wide latitudinal ranges in the northeast Pacific Ocean. In both species, females grew faster and larger than males. Growth of $S$. pinniger did not vary with latitude. For $S$. diploproa, however, there was a cline of increasing growth with higher latitude. In the habitat of the adult fish, which are demersal on the continental shelf and upper slope, latitudinal variation in environmental factors, such as temperature and oxygen concentration, appears insufficient to account for the observed differences in growth. Thus two other possible causes of the growth cline are discussed. First, $S$. diploproa has been exploited by fisheries more in the north than in the south, possibly resulting in more available prey and thus increased growth in the north (short term density-dependent response). The second possible cause is a density-independent, evolutionary response at the population level characterized by differences in reproductive strategy. Reproductive success in the southern part of the range of this species is probably less predictable due to the effects of oceanographic currents on the survival of epipelagic larvae and prejuveniles; reproductive effort in the south would therefore be greater. The relative importance of the suggested mechanisms for growth differences requires further elucidation from population genetics and studies of density effects and fishing pressure.
\end{abstract}

\section{INTRODUCTION}

Marine fishes inhabiting wide latitudinal ranges frequently show distinct variations in biological characteristics and life history strategies. Maximum size, longevity, age distribution, fecundity, and growth rate may vary in response to environmental factors, either through direct physiological mechanisms or through evolutionary responses to long-term environmental gradients at the population level. Latitudinal variation in growth rate has been studied in only a few species. Leggett and Carscadden (1978) observed faster growth with increasing latitude in the anadromous American shad (Alosa sapidissima), but correlated this difference with varying reproductive and life history strategies at the population level. Chadwick (1976), on the other hand, observed no differences in growth rate in either of two species of tidepool cottids from collections 1120 $\mathrm{km}$ apart on the Pacific coast. The evidence for latitudinal variation in growth in the scorpaenid genus

\footnotetext{
- Present address: School of Oceanography, Oregon State University, Corvallis, Oregon 97331, USA
}

Sebastes is conflicting; Westrheim (1973) observed more rapid growth in southern collections of $S$. alutus, whereas Love (1977) observed slower growth in $S$. serranoides collected in the warmer waters south of Point Conception as compared to those from cooler, northern waters. The present study compares growth of two species of Sebastes to analyze latitudinal variation in growth. The two species studied, Sebastes diploproa and $S$. pinniger, were chosen as representative of the genus; both have wide latitudinal ranges, from Baja California to southeastern Alaska (Hart, 1973). S. pinniger reaches maximum lengths of $76 \mathrm{~cm}$ and inhabits depths primarily from 91 to $183 \mathrm{~m}$ over hard bottoms (Miller and Gotshall, 1965; Hart, 1973). S. diploproa is smaller, reaching a maximum length of $46 \mathrm{~cm}$, and occurs in deeper water (to $578 \mathrm{~m}$ ) where it is associated with soft bottom (Hart, 1973). Age and growth have been analyzed for both species, but only for the following limited parts of the geographic ranges: California (Phillips, 1964), Oregon (Six and Horton, 1977) and British Columbia (Westrheim and Harling, 1975). These studies, taken as a whole, suggest that growth is faster in the southern parts of the range for both 
species. Conclusions drawn from different studies, however, may be misleading due to different collection methods and ageing methodologies. Therefore, in the present study we have sampled large numbers of individuals throughout the latitudinal range of each species.

\section{MATERIALS AND METHODS}

Both Sebastes pinniger and S. diploproa were collected in the 1977 Rockfish Survey undertaken by the Northwest and Alaska Fisheries Center (National Marine Fisheries Service) and several other cooperating agencies. Methods of sampling these species have been described (Gunderson and Sample, 1980). Sampling was conducted systematically from $34^{\circ} 09^{\prime} \mathrm{N}$ to $48^{\circ} 26^{\prime} \mathrm{N}$ latitude (Fig. 1) with trawling tracklines drawn perpendicular to the coast and spaced every 10 miles (every 5 miles in certain high-density areas). Along each trackline the following four depth intervals were sampled: $81-182 \mathrm{~m}, 183-273 \mathrm{~m}, 274-365 \mathrm{~m}$, and $366-476 \mathrm{~m}$. All sampling was with Nor'eastem trawls with roller gear, $8.9 \mathrm{~cm}$ mesh in the body with a $3.2 \mathrm{~cm}$ cod end liner. All measurements taken were fork length to the nearest $\mathrm{cm}$.

All otoliths were taken in the 1977 Rockfish Survey with the exception of 279 otoliths of Sebastes pinniger from California. In the southern part of its range (central and northern California), this species is generally not taken in trawls but enters the commercial longline fishery and the sport fishery (Miller and Gotshall, 1965). Otoliths collected by the California Department of Fish and Game from February 1977 to March 1978 were used in addition to a single collection from the Rockfish Survey to analyze growth for this species from California. Of the 279 otoliths from California, 171 were from males and 108 were from females; of the total, 173 were taken from commercial catches in the Eureka area and 106 were from the San Francisco sport catch.

Age was determined from whole otoliths, generally thought to be the best structure for age determination in Sebastes (Westrheim, 1973; Six and Horton, 1977; Kimura et al., 1979). Whole otoliths were read under reflected light at 10 magnifications on a dissecting microscope using the method of Westrheim (1973). No attempt was made to confirm the ages determined in this manner; it was assumed that each opaque-translucent ring pair constituted one year's growth. Annulus formation in young individuals has been demonstrated, however, by Kelly and Wolf (1959) for $S$. marinus and by Westrheim (1973) for $S$. alutus. The latter study also demonstrated the progression of a dominant year class of adults through the fishery over a period of 6 years, further validating the use of otoliths for age determination.

Growth data for both species were fit to the von Bertalanffy growth equation. Least square estimates for the parameters $L_{\infty}, k$, and $t_{0}$ were obtained using mean lengths at age weighted by the numbers of observations. Growth curves were compared using a predictive sample reuse procedure (Geisser and Eddy, 1979) modified for comparing growth curves (Kappenman, in prep.). This procedure chooses among alternative models with criteria based upon the lowest sums of squares of deviations within the alternative models. For comparing two populations, two alternative models are considered, model $M_{1}$ asserting that the two growth curves are the same, and model $\mathrm{M}_{2}$ asserting they are different. With three populations, on the other hand, five alternative models are considered: model $M_{1}$ asserts that the three populations are represented by a single growth curve; $M_{2}$, the first two populations are the same but differ from the third; $M_{3}$, the second and third populations are the same but differ from the first; $M_{4}$, the first and third populations are the same but differ from the second; and $\mathrm{M}_{5}$ all three populations are represented by separate growth curves. For

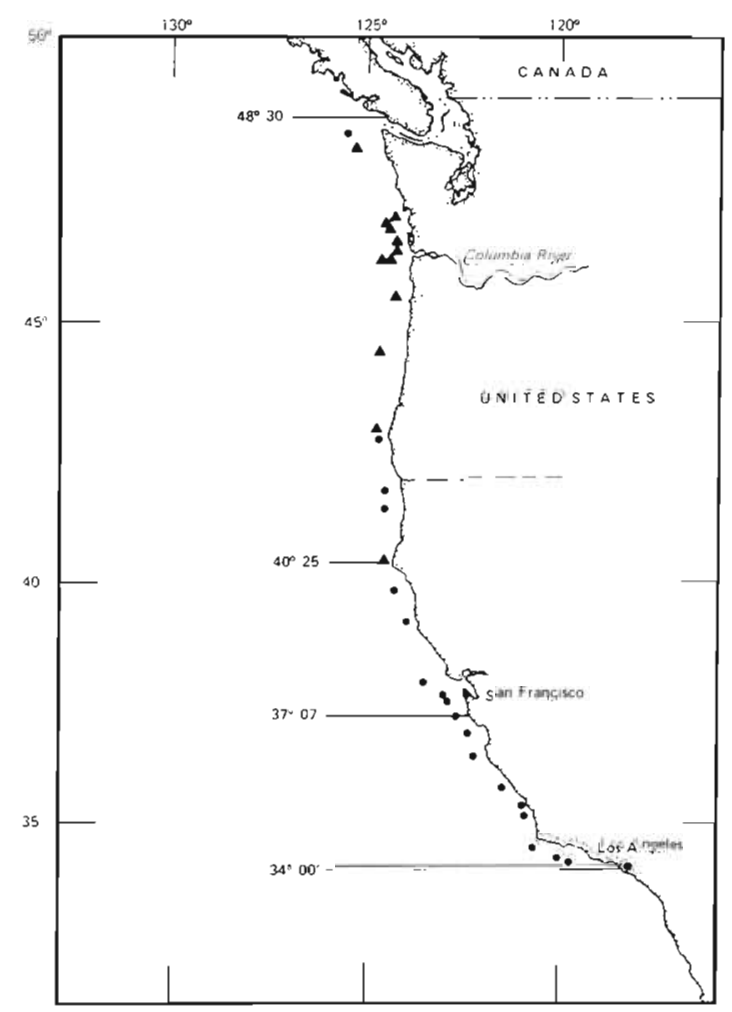

Fig. 1. Sebastes diploproa (circles) and S. pinniger (triangles). Geographic distribution of otolith collections from the 1977 Rockfish Survey. The boundaries for the three geographic areas for growth comparison of $S$. diploproa are indicated 
every alternative model $M_{n}$, sums of squares of deviations $D_{n}$ from a least squares fit of the relevant data are determined; the appropriate model is that with the lowest $D_{n}$ (Kappenman, in prep.).

\section{RESULTS}

\section{Sebastes diploproa}

Otoliths were collected from 1075 males and 751 females from $34^{\circ} 06^{\prime}$ to $48^{\circ} 06^{\prime} \mathrm{N}$ latitude. Based upon the distribution of samples, arbitrary latitudinal boundaries provided three geographic areas for growth comparison $\left(34^{\circ} 00^{\prime}\right.$ to $37^{\circ} 06^{\prime} \mathrm{N}$; $37^{\circ} 07^{\prime}$ to $40^{\circ} 25^{\prime} \mathrm{N}_{i}$ and $40^{\circ} 26^{\prime}$ to $48^{\circ} 30^{\prime} \mathrm{N}_{\text {; Fig. }}$ ). Numbers of specimens, mean length, and standard deviation of mean length are given for each age by sex and geographic area in Table 1 . For both sexes, mean sizes increased to the north, but this was primarily due to increased numbers of juveniles and fewer large specimens in the southern collections.

Growth curves for males and females show more rapid growth in the north (Fig. 2). Among the weighted sums of squares of deviations for the five alternative models (Table 2), $D_{5}$ is clearly the lowest for both males and females. Thus the selected model is $\mathrm{M}_{5}$, three different growth curves, indicating a cline of increasing growth to the north (Fig. 2, Table 1). For comparison by sex, $D_{2}$ was lowest, suggesting acceptance of $M_{2}$ and different growth between sexes in all geographic areas (Table 2). Females and males show similar growth rates through ages 9 to 11 , after which females grow more rapidly than males (Table 1).

Weighted least squares estimates of Bertalanffy parameters are presented in Table 3 for the present study and also from Phillips (1964) and Westrheim and Harling (1975). Parameter values, growth curves, and maximum ages from the northern geographic area compare favorably with thoses of Westrheim and Harling (1975); in the southern geographic area, however, the values reported in Phillips (1964) differ greatly. Westrheim and Harling (1975) determined age from otoliths (as in the present study), whereas Phillips (1964) used scales, fewer specimens, and back calculations. For slow growing, long-lived species such as Sebastes diploproa, scale annuli may become indistinct near the margin, making age determination of large, older individuals difficult. Westrheim and Harling (1973) compared scale and otolith age determina-

Table 1. Sebastes diploproa. Numbers of otoliths (N), mean lengths-at-age (L), and standard deviation of mean length-at-age (s) for males and females from three geographic areas

\begin{tabular}{|c|c|c|c|c|c|c|c|c|c|c|c|c|c|c|c|c|c|c|}
\hline \multirow{3}{*}{$\begin{array}{c}\text { Age } \\
\text { (years) }\end{array}$} & \multicolumn{6}{|c|}{$34^{\circ} 00^{\prime}$ to $37^{\circ} 06^{\prime}$} & \multicolumn{6}{|c|}{$37^{\circ} 07^{\prime}$ to $40^{\circ} 25^{\prime}$} & \multicolumn{6}{|c|}{$40^{\circ} 26^{\prime}$ to $48^{\circ} 30^{\prime}$} \\
\hline & \multicolumn{3}{|c|}{ Males } & \multicolumn{3}{|c|}{ Females } & \multicolumn{3}{|c|}{ Males } & \multicolumn{3}{|c|}{ Females } & \multicolumn{3}{|c|}{ Males } & \multicolumn{3}{|c|}{ Females } \\
\hline & $\mathrm{N}$ & L & $\mathrm{s}$ & $\mathrm{N}$ & L & $\mathrm{s}$ & $\mathrm{N}$ & L & $\mathrm{s}$ & $N$ & L & $\mathrm{s}$ & $\mathrm{N}$ & L & $s$ & $\mathrm{~N}$ & L & $\mathbf{s}$ \\
\hline 1 & 10 & 8.7 & 0.7 & 6 & 9.3 & 0.8 & 0 & - & - & 0 & - & - & 0 & - & - & 0 & - & - \\
\hline 2 & 23 & 10.8 & 1.0 & 26 & 10.3 & 1.0 & 0 & - & - & 0 & - & - & 1 & 16.0 & 0.0 & 0 & - & - \\
\hline 3 & 36 & 12.7 & 1.1 & 33 & 12.9 & 1.3 & 2 & 15.5 & 2.1 & 1 & 16.0 & 0.0 & 9 & 16.2 & 0.4 & 9 & 17.1 & 0.8 \\
\hline 4 & 19 & 14.4 & 1.3 & 11 & 13.6 & 1.3 & 2 & 18.0 & 0.0 & 6 & 16.5 & 0.6 & 8 & 18.5 & 1.5 & 13 & 17.8 & 1.2 \\
\hline 5 & 7 & 17.3 & 1.7 & 5 & 14.4 & 1.3 & 9 & 18.6 & 1.5 & 14 & 18.9 & 1.3 & 17 & 20.2 & 1.3 & 11 & 20.3 & 1.4 \\
\hline 6 & 19 & 17.0 & 1.9 & 9 & 16.7 & 1.9 & 18 & 20.3 & 1.5 & 18 & 19.8 & 1.2 & 10 & 21.0 & 0.7 & 10 & 21.8 & 1.0 \\
\hline 7 & 15 & 18.5 & 2.3 & 10 & 19.9 & 2.8 & 17 & 21.4 & 1.4 & 15 & 21.3 & 0.7 & 10 & 21.6 & 0.8 & 9 & 24.1 & 2.0 \\
\hline 8 & 14 & 20.8 & 2.1 & 9 & 21.6 & 1.9 & 17 & 22.1 & 1.9 & 9 & 22.1 & 0.9 & 4 & 24.0 & 0.8 & 7 & 24.9 & 1.3 \\
\hline 9 & 5 & 22.8 & 1.5 & 9 & 22.3 & 0.9 & 18 & 23.0 & 1.6 & 15 & 24.0 & 1.1 & 15 & 26.1 & 1.3 & 5 & 25.4 & 1.7 \\
\hline 10 & 17 & 23.1 & 1.1 & 13 & 22.6 & 1.1 & 14 & 23.4 & 1.7 & 14 & 25.1 & 1.0 & 15 & 26.2 & 1.2 & 13 & 27.1 & 1.0 \\
\hline 11 & 19 & 23.1 & 1.1 & 15 & 24.0 & 1.3 & 18 & 24.4 & 1.0 & 10 & 25.4 & 1.3 & 10 & 26.9 & 1.5 & 9 & 27.4 & 1.5 \\
\hline 12 & 17 & 24.4 & 1.3 & 15 & 24.7 & 1.7 & 21 & 24.8 & 1.6 & 8 & 26.5 & 2.0 & 19 & 26.6 & 1.3 & 5 & 27.4 & 1.1 \\
\hline 13 & 33 & 24.9 & 1.2 & 12 & 25.8 & 1.7 & 26 & 25.7 & 1.0 & 6 & 26.2 & 1.7 & 17 & 27.7 & 1.4 & 5 & 29.8 & 1.6 \\
\hline 14 & 50 & 25.1 & 1.3 & 26 & 26.2 & 1.2 & 24 & 26.3 & 1.5 & 4 & 27.8 & 1.0 & 20 & 28.3 & 1.7 & 5 & 30.0 & 1.6 \\
\hline 15 & 43 & 26.0 & 1.4 & 32 & 27.2 & 1.6 & 35 & 26.5 & 1.5 & 8 & 28.9 & 1.6 & 16 & 28.4 & 2.0 & 13 & 29.6 & 1.9 \\
\hline 16 & 28 & 26.1 & 1.0 & 33 & 27.4 & 1.5 & 25 & 27.1 & 1.1 & 7 & 29.1 & 1.2 & 21 & 29.2 & 1.7 & 5 & 32.0 & 1.2 \\
\hline 17 & 25 & 26.7 & 1.1 & 45 & 28.2 & 1.4 & 29 & 27.3 & 1.4 & 9 & 30.0 & 1.2 & 29 & 30.1 & 1.6 & 8 & 32.6 & 1.3 \\
\hline 18 & 19 & 26.8 & 1.4 & 25 & 28.4 & 1.2 & 18 & 28.3 & 1.5 & 11 & 29.7 & 1.1 & 15 & 30.2 & 1.5 & 17 & 33.6 & 3.2 \\
\hline 19 & 12 & 27.2 & 2.2 & 23 & 29.4 & 1.5 & 14 & 28.6 & 1.3 & 6 & 29.8 & 1.8 & 10 & 30.0 & 2.0 & 5 & 31.4 & 1.8 \\
\hline 20 & 8 & 28.0 & 1.2 & 18 & 29.9 & 1.7 & 7 & 29.0 & 1.6 & 6 & 30.0 & 1.7 & 15 & 31.5 & 2.1 & 6 & 34.3 & 2.2 \\
\hline 21 & 8 & 27.8 & 2.1 & 11 & 30.6 & 0.9 & 6 & 28.8 & 1.0 & 4 & 31.0 & 1.2 & 12 & 31.5 & 1.7 & 8 & 34.9 & 2.2 \\
\hline 22 & 2 & 27.5 & 2.1 & 7 & 30.4 & 1.0 & 6 & 30.3 & 1.5 & 2 & 30.5 & 2.1 & 4 & 32.5 & 0.6 & 9 & 34.3 & 1.9 \\
\hline 23 & 1 & 27.0 & - & 3 & 30.7 & 0.6 & 5 & 31.4 & 0.9 & 2 & 34.5 & 2.1 & 12 & 31.6 & 1.2 & 3 & 35.3 & 1.5 \\
\hline 24 & 0 & - & - & 2 & 31.0 & 1.4 & 3 & 32.6 & 0.6 & 0 & - & 0.0 & 5 & 32.6 & 1.5 & 4 & 34.8 & 1.0 \\
\hline 25 & 0 & - & - & 1 & 33.0 & 0.0 & 3 & 31.0 & 1.0 & 2 & 32.5 & 0.7 & 8 & 31.9 & 1.2 & 3 & 35.0 & 2.0 \\
\hline $26+$ & 0 & - & - & 0 & - & - & 2 & 30.0 & 1.4 & 1 & 35.0 & 0.0 & 4 & 32.5 & 0.6 & 2 & 36.0 & 2.9 \\
\hline
\end{tabular}



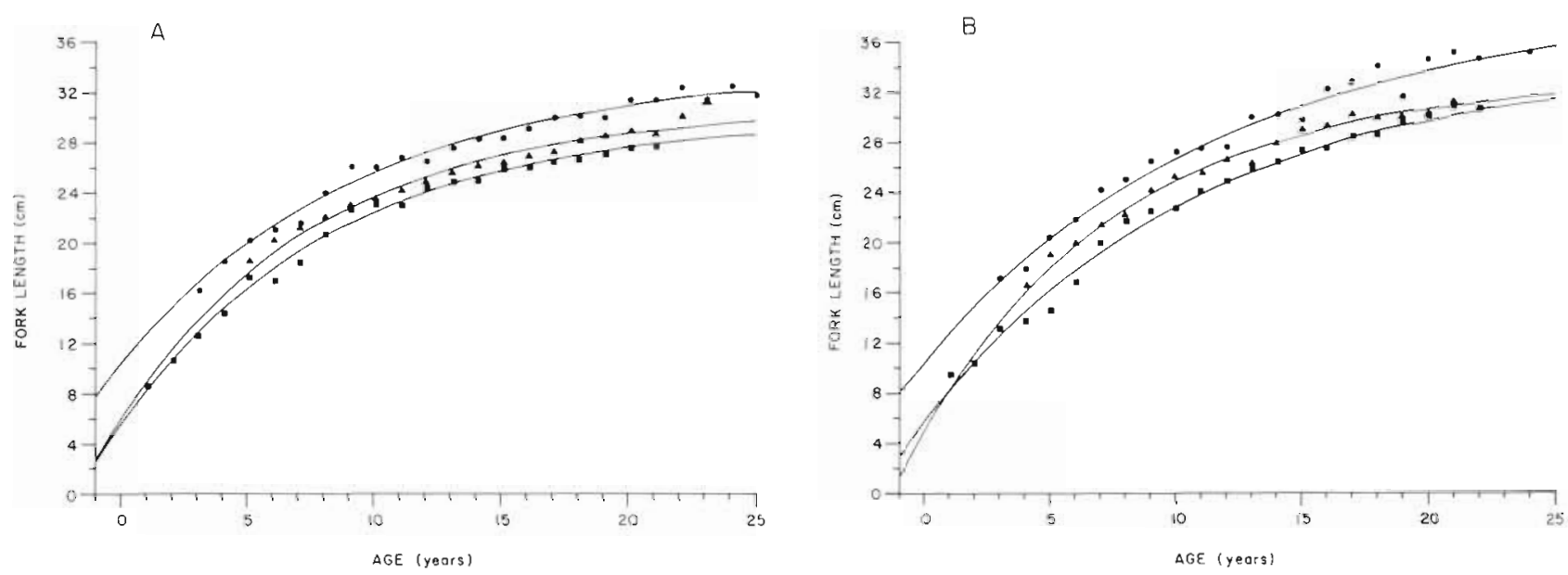

Fig. 2. Sebastes diploproa. Fitted growth curves and mean lengths-at-age from the three geographic areas (Fig. 1); only mean lengths represented by four or more observations are shown. A: Males; B: Females. Squares: southern geographic area; triangles: central geographic area; circles: northern geographic area

tions from the same specimens of S. alutus; ages determined from otoliths were greater than those from scales in $53 \%$, equal in $40 \%$, and less in $7 \%$. More importantly, the positive deviations of otolith ages increased with increasing age, reaching 8 years for an individual 21 years old (as determined by the otolith). If this is indeed the case in the data of Phillips (1964), the use of backcalculated values in determining growth could cause positive bias in the estimates of younger age groups as well as underestimating maximum ages (Maraldo and MacCrimmon, 1979).

\section{Sebastes pinniger}

Rockfish Survey and California Fish and Game collections provided otoliths from 817 males and 557 females. Sebastes pinniger has a more restricted geographic range of significant abundance than does $S$. diploproa (Gunderson and Sample, 1980) and the otolith collections were distributed accordingly. Two geographic areas were arbitrarily chosen based upon the numbers of otoliths; the southern area was bounded by $37^{\circ} 06^{\prime}$ to $45^{\circ} 00^{\prime} \mathrm{N}$ latitude, the northern

Table 2. Sebastes pinniger and S. diploproa. Weighted sums of squares of deviations $D_{n}$ for the alternative models $M_{n}$ for growth comparisons. In two-way comparisons, the models are as follows: in $M_{1}$ the two growth curves are the same; in $M_{2}$, they are different. For three-way comparisons, the models are represented by: $\mathrm{M}_{1}$, all populations characterized by the same $g r o w t h$ curve, $M_{2}$, the first two populations are the same but differ from the third; $M_{3}$, the second and third populations are the same but differ from the first; $M_{4}$, the first and third populations are the same but differ from the second; and $M_{5}$, all three populations are represented by separate growth curves

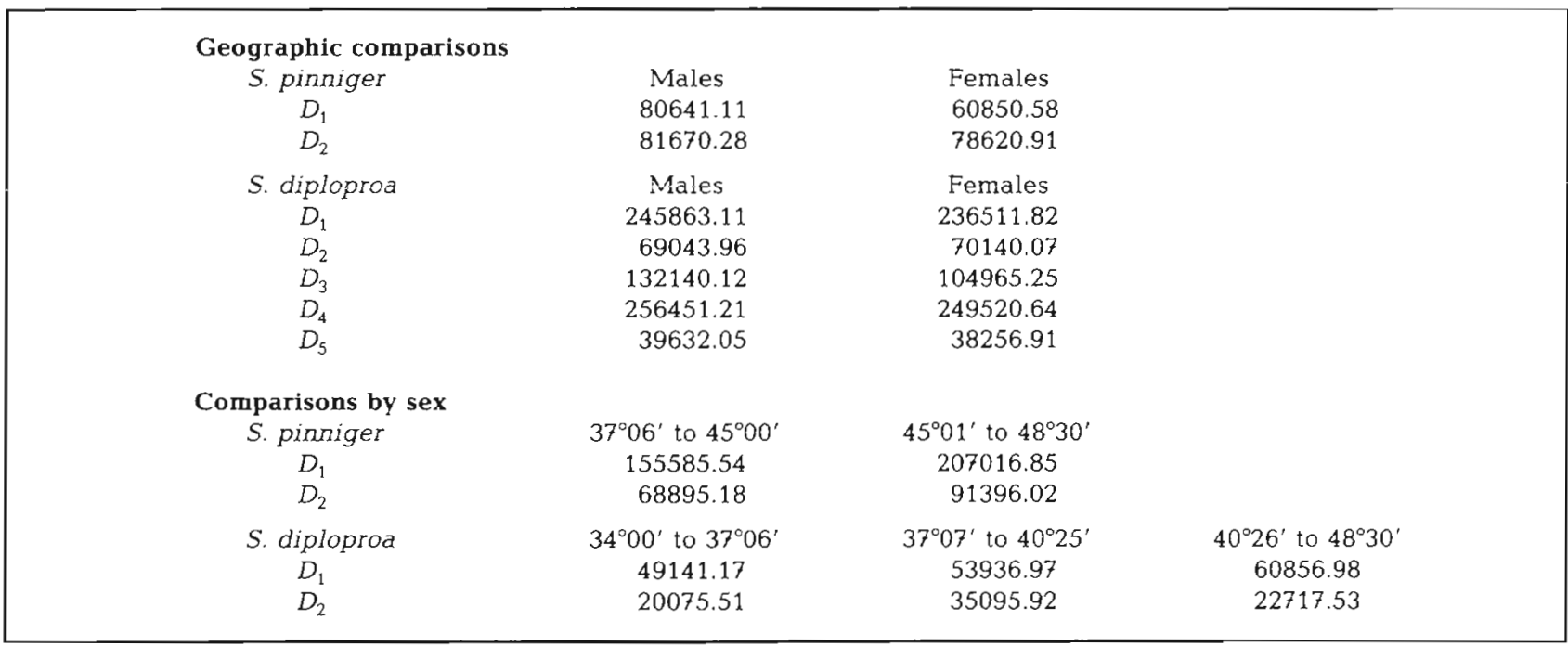


area by $45^{\circ} 01^{\prime}$ to $48^{\circ} 30^{\prime} \mathrm{N}$ latitude. Age-length data for males and females in the two areas are presented in Table 4. Within sexes, mean lengths at age for older specimens are slightly greater in the north. For both males and females, however, the weighted sum of squares of deviations was lower for $\mathrm{M}_{1}$ (Table 2), suggesting acceptance of a single growth curve and therefore lack of latitudinal differences in growth. As in $S$. diploproa, however, analysis of differences by sex suggests acceptance of $M_{2}$, different growth curves by sex (Table 2); females grow faster than males (Table 4, Fig. 3). Growth between sexes is similar through age 11, after which mean lengths of females are greater than those of males at a given age.

Weighted least squares estimates of Bertalanffy parameters for males and females of Sebastes pinniger (geographic areas combined) are presented in Table 5 with comparative values from Phillips (1964), Six and Horton (1977), and Westrheim and Harling (1975). Most of the individuals examined in the present study were collected in the area offshore from the Columbia River (Fig. 1), a geographic area similar to the areas of collections of Six and Horton (1977). Age determinations and resulting growth curves from the two studies

Table 3. Sebastes diploproa. Bertalanffy-parameter estimates. TL: total length; FL: fork length. Areas in the present study are (1) $34^{\circ} 00^{\prime}$ to $37^{\circ} 06^{\prime} \mathrm{N}$, (2) $37^{\circ} 07^{\prime}$ to $40^{\circ} 25^{\prime} \mathrm{N}$, (3) $40^{\circ} 26^{\prime}$ to $48^{\circ} 30^{\prime} \mathrm{N}$. N: number of individuals. The number in parentheses for Phillips (1964) represents the number of observations, including back calculations, taken from the 92 individuals used to fit the growth curve

\begin{tabular}{|c|c|c|c|c|c|c|c|c|c|}
\hline \multirow{3}{*}{$\begin{array}{l}\text { Study } \\
\text { Area } \\
\text { Sex } \\
\text { Measurement }\end{array}$} & \multirow{3}{*}{$\begin{array}{c}\text { Phillips (1964) } \\
\text { California } \\
\text { Combined } \\
\text { TL }\end{array}$} & \multirow{2}{*}{\multicolumn{2}{|c|}{$\begin{array}{c}\text { Westrheim \& Harling (1975) } \\
\text { British Columbia }\end{array}$}} & \multicolumn{6}{|c|}{ Present study } \\
\hline & & & & \multirow[t]{2}{*}{1} & \multirow{2}{*}{$\begin{array}{c}2 \\
\text { Males } \\
\text { FL }\end{array}$} & 3 & 1 & \multirow{2}{*}{$\begin{array}{c}2 \\
\text { Females } \\
\text { FL }\end{array}$} & \multirow{2}{*}{$\begin{array}{l}3 \\
\mathrm{FL}\end{array}$} \\
\hline & & $\begin{array}{c}\text { Males } \\
\text { FL }\end{array}$ & $\begin{array}{l}\text { Females } \\
\text { FL }\end{array}$ & & & FL & FL & & \\
\hline$L_{\infty}(\mathrm{cm})$ & 41.8 & 32.7 & 36.8 & 30.04 & 30.58 & 33.84 & 34.33 & 32.95 & 38.91 \\
\hline$k$ & 0.123 & 0.14 & 0.10 & 0.117 & 0.129 & 0.105 & 0.091 & 0.125 & 0.084 \\
\hline$t_{0}$ & -0.408 & -0.9 & -1.5 & -1.76 & -1.62 & -3.46 & -2.01 & -1.30 & -3.69 \\
\hline Max. age & 16 & 28 & 28 & 23 & 28 & 29 & 25 & 28 & 30 \\
\hline$N$ & $92(803)$ & 260 & 245 & 430 & 339 & 306 & 399 & 178 & 174 \\
\hline \multirow{3}{*}{$\begin{array}{l}\text { Predicted length } \\
(\mathrm{cm}) \text { at age (years) }\end{array}$} & $5: 20.3$ & 18.4 & 17.6 & 16.4 & 17.6 & 19.9 & 16.2 & 18.0 & 20.2 \\
\hline & $10: 30.2$ & 25.6 & 25.1 & 22.5 & 23.7 & 25.6 & 22.8 & 24.9 & 26.6 \\
\hline & $20: 38.4$ & 30.9 & 32.5 & 27.7 & 28.7 & 31.0 & 29.7 & 30.7 & 33.6 \\
\hline
\end{tabular}

Table 4. Sebastes pinniger. Numbers of otoliths (N), mean lengths-at-age (L), and standard deviation of length-at-age (s) for males and females from two geographic areas

\begin{tabular}{|c|c|c|c|c|c|c|c|c|c|c|c|c|}
\hline \multirow{3}{*}{$\begin{array}{c}\text { Age } \\
\text { (years) }\end{array}$} & \multicolumn{6}{|c|}{$37^{\circ} 06^{\prime}$ to $45^{\circ} 00^{\prime}$} & \multicolumn{6}{|c|}{$45^{\circ} 01^{\prime}$ to $48^{\circ} 30^{\prime}$} \\
\hline & \multicolumn{3}{|c|}{ Males } & \multicolumn{3}{|c|}{ Females } & \multicolumn{3}{|c|}{ Males } & \multicolumn{3}{|c|}{ Females } \\
\hline & $N$ & L & $\mathrm{s}$ & $\mathrm{N}$ & $\mathrm{L}$ & $\mathrm{s}$ & $\mathrm{N}$ & L. & $\mathrm{s}$ & $N$ & L & $\mathrm{s}$ \\
\hline 3 & 0 & - & - & 0 & - & - & 3 & 23.0 & 1.7 & 4 & 21.3 & 2.3 \\
\hline 4 & 3 & 25.8 & 2.3 & 8 & 27.3 & 1.9 & 8 & 28.3 & 3.8 & 10 & 27.0 & 4.6 \\
\hline 5 & 6 & 30.5 & 4.0 & 8 & 31.1 & 3.0 & 32 & 30.1 & 2.9 & 17 & 31.6 & 3.9 \\
\hline 6 & 10 & 31.9 & 2.3 & 8 & 32.2 & 2.9 & 45 & 33.3 & 2.6 & 29 & 33.6 & 2.6 \\
\hline 7 & 6 & 36.6 & 2.4 & 8 & 35.8 & 3.1 & 21 & 36.1 & 2.6 & 22 & 36.9 & 3.5 \\
\hline 8 & 7 & 41.6 & 2.6 & 7 & 39.8 & 3.0 & 31 & 42.7 & 2.2 & 20 & 40.8 & 3.1 \\
\hline 9 & 27 & 44.1 & 2.0 & 17 & 43.2 & 3.3 & 80 & 43.3 & 3.3 & 48 & 44.5 & 2.9 \\
\hline 10 & 37 & 46.0 & 2.4 & 18 & 46.7 & 2.8 & 64 & 45.1 & 2.4 & 54 & 46.6 & 2.2 \\
\hline 11 & 25 & 47.7 & 2.7 & 14 & 49.5 & 2.3 & 32 & 46.3 & 3.2 & 34 & 47.4 & 3.0 \\
\hline 12 & 27 & 48.4 & 3.4 & 22 & 51.7 & 2.4 & 32 & 49.1 & 2.3 & 9 & 50.7 & 3.1 \\
\hline 13 & 29 & 48.5 & 3.2 & 25 & 52.1 & 3.1 & 53 & 50.1 & 1.8 & 17 & 53.2 & 2.4 \\
\hline 14 & 29 & 50.3 & 1.7 & 27 & 53.9 & 2.5 & 62 & 51.1 & 2.2 & 30 & 54.9 & 2.6 \\
\hline 15 & 12 & 50.5 & 2.4 & 17 & 55.4 & 1.7 & 39 & 51.1 & 2.0 & 26 & 55.3 & 2.6 \\
\hline 16 & 13 & 51.7 & 2.7 & 4 & 55.7 & 1.9 & 33 & 52.4 & 2.2 & 24 & 56.8 & 3.5 \\
\hline 17 & 10 & 51.7 & 2.5 & 8 & 54.6 & 2,4 & 22 & 53.0 & 2.6 & 8 & 54.9 & 2.7 \\
\hline 18 & 4 & 51.5 & 1.8 & 6 & 56.7 & 1.9 & 10 & 53.1 & 2.4 & 4 & 57.8 & 4.8 \\
\hline 19 & 2 & 52.5 & 0.7 & 1 & 58.6 & - & 2 & 53.5 & 0.7 & 0 & - & - \\
\hline 20 & 1 & 48.0 & - & 2 & 59.5 & 3.1 & 0 & - & - & 1 & 62.0 & - \\
\hline 21 & 0 & - & - & 0 & - & - & 0 & - & - & 0 & - & - \\
\hline
\end{tabular}




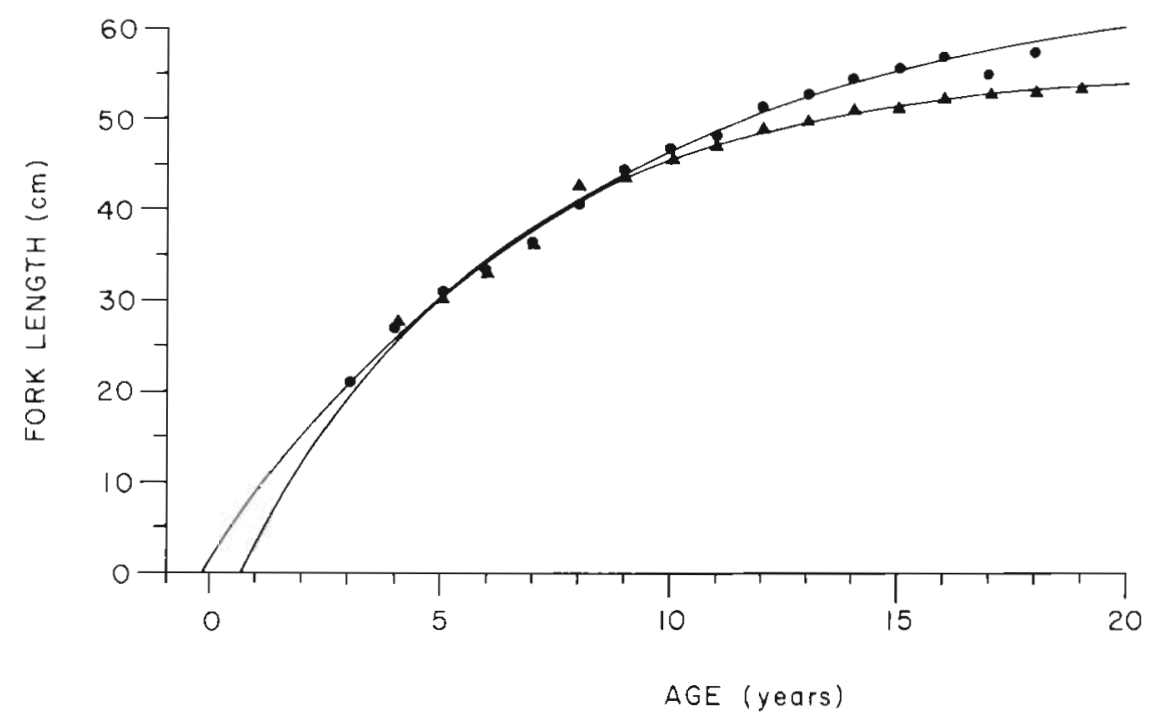

Fig. 3. Sebastes pinniger. Fitted growth curves and mean lengths-at-age for combined collections of males (triangles) and females (circles). Only mean lengths represented by four or more observations are shown

are similar (Table 5). The values of Westrheim and Harling (1975) suggest lower mean lengths at age, but the numbers of age determinations are relatively low. The data from Phillips (1964) are similar, considering that he measured total length rather than fork length and combined both sexes. Age determination with scales is probably appropriate for this species; Six and Horton (1977) showed a close correspondence of age determined from scales and otoliths from the same specimens but greater consistency between readers for otoliths than scales.

\section{DISCUSSION}

Westrheim and Harling (1975) studied growth of northern and southern collections of 8 species of Sebastes through comparison of predicted lengths at ages of 10 and 20 years. Individuals of S. babcocki and $S$. zacentrus had greater predicted lengths in British
Columbia than in Alaska, indicating faster growth in the south, whereas no difference was apparent for $S$. aleutianus. Westrheim and Harling (1975) compared their data from British Columbia with that of Phillips (1964) from California, and suggested faster growth in southern populations of 5 rockfish $(S$. crameri, $S$. diploproa, S. entomelas, S. flavidus, and S. pinniger). A similar latitudinal cline was demonstrated for $S$. alutus by Westrheim (1973).

Contrary to these comparisons, we observed no differences in growth with latitude for Sebastes pinniger and faster growth in the northern collections for $S$. diploproa (Figs 2 and 3, Table 2). These results suggest caution in comparing age and growth determined by different investigators, particularly in species for which age determination has not been validated. For both $S$. diploproa and $S$. pinniger, females grew faster than males (Fig. 3, Table 2); this is in agreement with past observations on the following rockfish: S. alutus (Westrheim, 1973), S. marinus (Kelly and Wolf, 1959),

Table 5. Sebastes pinniger. Bertalanffy-parameter estimates. Abbreviations as in Table 3

\begin{tabular}{|c|c|c|c|c|c|c|c|}
\hline \multirow{3}{*}{$\begin{array}{l}\text { Study } \\
\text { Area } \\
\text { Sex }\end{array}$} & \multirow{3}{*}{$\begin{array}{c}\begin{array}{c}\text { Phillips (1964) } \\
\text { California }\end{array} \\
\text { Combined }\end{array}$} & \multirow{2}{*}{\multicolumn{2}{|c|}{$\begin{array}{c}\text { Six and Horton (1977) } \\
\text { Oregon }\end{array}$}} & \multirow{2}{*}{\multicolumn{2}{|c|}{$\begin{array}{c}\text { Westrheim \& Harling (1975) } \\
\text { British Columbia }\end{array}$}} & \multirow{2}{*}{\multicolumn{2}{|c|}{$\begin{array}{l}\text { Present study } \\
37^{\circ} 06^{\prime} \text { to } 48^{\circ} 30^{\prime}\end{array}$}} \\
\hline & & & & & & & \\
\hline & & Males & Females & Males & Females & Males & Females \\
\hline Measurement & TL & FL & FL & FL & FL & FL & FL \\
\hline$L \infty(\mathrm{cm})$ & 65.5 & 53.60 & 60.95 & 51.8 & 56.9 & 55.72 & 66.11 \\
\hline$k$ & 0.122 & 0.189 & 0.146 & 0.16 & 0.15 & 0.178 & 0.118 \\
\hline$t_{0}$ & -0.402 & 0.681 & 0.537 & 0.5 & 0.9 & 0.595 & -0.240 \\
\hline Max. age & 18 & 20 & 21 & 26 & 26 & 20 & 20 \\
\hline $\mathrm{N}$ & $143(1285)$ & \multicolumn{2}{|c|}{ not stated } & 61 & 24 & 817 & 557 \\
\hline Predicted length & $5: 31.6$ & 29.9 & 29.2 & 26.6 & 26.1 & 30.3 & 30.5 \\
\hline \multirow[t]{2}{*}{$(\mathrm{cm})$ at age: } & $10: 47.1$ & 44.4 & 45.6 & 40.5 & 42.4 & 45.3 & 46.4 \\
\hline & $20: 60.1$ & 52.2 & 57.4 & 49.5 & 53.7 & 54.0 & 60.0 \\
\hline
\end{tabular}


S. pinniger, $S$. flavidus, and $S$. melanops (Six and Horton, 1977), among others. The greatest differences in growth between sexes is attained after the age and size of sexual maturity (Phillips, 1964; Gunderson et al., 1980).

We will consider three possible explanations for the observed trend in growth for Sebastes diploproa. The first is an immediate response at the individual level based upon the physiological effects of environmental parameters. The second is a short-term response at the population level based upon density-dependent regulation. The third is a long-term response but densityindependent, since it involves genetic differences and evolutionary responses at the population level. We consider the evidence for each explanation below.

Analysis of physiological differences in growth must consider the immediate effects of physical factors which vary over the latitudinal range of the species. The depth of maximum biomass for Sebastes diploproa is approximately $300 \mathrm{~m}$ (Gunderson and Sample, 1980); over the latitudinal range of this species, the important parameters at this depth are temperature and dissolved oxygen. At $300 \mathrm{~m}$, as one proceeds between $34^{\circ} 00^{\prime}$ and $48^{\circ} 00^{\prime} \mathrm{N}$ latitude, mean temperature decreases from $7.3^{\circ}$ to $6.2^{\circ} \mathrm{C}$, and mean dissolved oxygen increases from 1.40 to $1.85 \mathrm{ml} \mathrm{l}^{-1}$; seasonal variations are approximately $0.3^{\circ} \mathrm{C}$ and $0.1 \mathrm{ml} \mathrm{l^{-1 }}$ (Chingin and Halminski, 1974). Higher temperatures usually result in an increase in the rate of growth (Bertalanffy's $k$ ) but a decrease in maximum predicted size ( $\left.L_{\infty}\right)$ (Beverton and Holt, 1959). Mean size and maximum size of $S$. diploproa increase with depth and latitude in accordance with the decreased temperature (Boehlert, 1980). Reduced dissolved oxygen may decrease growth (Stewart et al., 1967). The interplay between temperature and dissolved oxygen may be important here, however, as levels of dissolved oxygen critical for growth are inversely related to temperature (Doudoroff and Shumway, 1970); unfortunately, the oxygen requirements of $S$. diploproa are unknown. In general, these physical differences would not appear sufficient to cause the observed latitudinal differences in growth in $S$. diploproa; indeed, based upon the direction of change, one would expect increased growth in the southern rather than the northern areas, as observed for $S$. alutus by Westrheim (1973).

Another factor which affects growth is food availability. Sebastes diploproa feeds almost exclusively on euphausids (Phillips, 1964). Unfortunately no information is available on biomass and availability of euphausids over the geographic range of $S$. diploproa; density-dependent mechanisms, however, may implicate food availability indirectly in the observed trend of growth. For $S$. diploproa, there has been no directed fishery in the southern part of its range since the early 1960's (Heimann, 1963), although it has been taken incidentally in the animal food fishery (Nitsos and Reed, 1965). Data from the 1977 Rockfish Survey (Gunderson and Sample, 1980) show the maximum biomass of $S$. diploproa in the two southernmost areas for growth analysis in the present study. In the northern part of its range no directed fishery exists for $S$. diploproa; it is, however, the species most closely associated with catches of $S$. alutus (Alverson and Westrheim, 1961), and stocks of S. alutus in the northeastern Pacific have declined drastically due to overfishing (Gunderson, 1977). Large-scale removals of $S$. diploproa as incidental catch (recorded as 'other rockfish') are likely. Although biomass data on northern $S$. diploproa previous to 1977 are unavailable, the length frequencies from the 1977 Rockfish Survey (Boehlert, 1980), as compared to those from Alverson et al. (1964), show a dramatic decrease in mean size and size distribution in recent data, indicative of probable stock reduction (Boehlert, 1980). The reduction of stocks of $S$. alutus has been suggested as a factor in the southward extension of the ranges of northern species of Sebastes and the walleye pollock, Theragra chalcogramma (Snytko and Federov, 1974). Density-dependent regulation of fish populations in the adult stage is generally restricted to changes in growth (Jones, 1973); for example, Margetts and Holt (1948) observed increased density and decreased individual growth in plaice (Pleuronectes platessa) during cessation of the fishery in 1939 to 1945 , but decreased density and increased individual growth after fishing resumed. Some evidence therefore exists for the hypothesis that the increased growth in the northern part of the range of $S$. diploproa is the result of density-dependent regulation of growth.

The final explanation is based upon latitudinal variation in life-history strategy and thus requires the assumption of reproductive isolation of sub-populations of Sebastes diploproa. Many species with latitudinal variations in life history spawn in restricted areas; the variations may be related to population structure. Leggett and Carscadden (1978) observed faster growth, decreased relative fecundity, and increasing proportions of repeat spawners with increasing latitude in populations of the American shad Alosa sapidissima, which exist in reproductively isolated populations. Similarly, mean size of spawner in anadromous steelhead Salmo gairdneri increases with increasing latitude (Withler, 1966). Genetic differences and reproductive isolation have been suggested for some species of Sebastes. Three subpopulations of $S$. alutus (Gulf of Alaska, Prince William Sound, and Oregon-British Columbia) exist in the northern Pacific (Wishard et al., 1980); it appears that the latitudinal growth differences observed by Westrheim (1973) are 
associated with subpopulation structure. Westrheim (1973) further noted bathymetric variations in growth rate in the same areas and later suggested reproductive differences between shallow and deep populations (Westrheim, 1975). Preliminary electrophoretic evidence suggests that two subpopulations of $S$. pinniger may exist (Wishard et al., 1980), but no corresponding differences in growth rate were detected for this species. Tsuyuki et al. (1968) demonstrated two electrophoretic hemoglobin variants in $S$. diploprod, but could not associate these patterns with geographic or bathymetric distribution. The geographic extent of their samples, however, corresponded only to the northern, fastest growing segment of the population in the present study.

Although Sebastes species are ovoviviparous, larvae are pelagic (Ahlstrom 1961) and may have extended pelagic periods lasting up to a year (Boehlert, 1977; Moser and Ahlstrom, 1978). Although subpopulations may be mixed during the pelagic phase, it has been suggested that localized eddies of the California current may alter recruitment patterns of certain species (Love and Larsen, 1978). Furthermore, Gunderson (1972) demonstrated that $S$. alutus forms aggregations with different biological characteristics, and Carlson and Haight (1972) provided evidence for homing behavior in S. flavidus; it is thus plausible that even stocks mixed during the pelagic stage may return to separate reproductive populations later in the life history.

Habitats with differing environmental stability may select for reproductive strategies and, therefore, differential partitioning of energy to reproduction and growth. Where reproductive success is unpredictable from year to year, species may exhibit either iteroparity or increased fecundity, often at the expense of somatic growth (Murphy, 1968; Charnov and Schaffer, 1973; Schaffer and Elson, 1975). Variations in reproductive strategy are observed within species characterized by wide latitudinal or bathymetric distributions. We have already referred to the case of the American shad (Leggett and Carscadden, 1978) and the steelhead (Withler, 1966), both anadromous species with wide latitudinal ranges. The trend in principal parturition season for Sebastes diploproa is towards a shorter and later season as one proceeds northward (Boehlert, 1977), although some variations have been observed (Westrheim, 1975). In the population south of Point Conception, there is apparently year-round spawning (Boehlert, unpublished). Fecundity of Sebastes spp. is generally related to weight (Gunderson et al., 1980) and no latitudinal trends have been documented within species. Multiple spawning, however, which may increase realized yearly fecundity occurs in several southern species (Moser, 1967; MacGregor, 1970).
Increased reproductive effort in the southern part of the range of $S$. diploproa may, therefore, bear some relationship to the decreased somatic growth reported in the present study.

Serious consideration of this latter hypothesis requires some factor making reproductive success less predictable in the south than in the north. Physical conditions in the adult habitat show little variation, as discussed earlier. In the pelagic larval habitat, however, oceanographic conditions over the latitudinal range may affect survival and recruitment differentially. Parrish (1977) predicted that species spawning between Point Conception $\left(34^{\circ} 16^{\prime} \mathrm{N}\right)$ and Cape Mendocino $\left(40^{\circ} 25^{\prime} \mathrm{N}\right)$ would suffer large scale losses of epipelagic eggs and larvae due to initial offshore Ekman transport and subsequent southerly transport in the California current. Ekman transport in this region is generally offshore during the spawning season of this species but is variable from year to year (Bakun, 1975). North of Cape Mendocino, however, offshore Ekman transport is less pronounced (Bakun, 1975) and off Washington geostrophic flow may bring epipelagic eggs and larvae towards shore (Parrish, 1977). Thus if genetic differences and reproductive isolation exist for Sebastes diploproa, we would suggest that Cape Mendocino would be the breakpoint between northern and southern populations; this corresponds to the boundary between the central and northern populations in the present study. It is significant in this regard that model $M_{2}$ in the present study has the second lowest sum of squares $\left(D_{2}\right)$ for both male and female geographic comparisons (Table 2); this model predicts that the southern and central populations are represented by a single growth curve but differ from the northern population in growth characteristics.

The alternative hypotheses posed above relate to different time scales of population response. The first is based upon the short term response to differential fishing mortality over the range of the species. Differences in growth are, therefore, a simple densitydependent mechanism. The second hypothesis is based upon density-independent, evolutionary responses at the population level; it follows theoretical predictions of live history patterns in response to environmental predictability (Murphy, 1968). Testing these alternative hypotheses will require a cessation of the fishery in the north and analysis of genetic population differences over the range. The first hypothesis would be supported if growth decreased in the north as density increased and if no genetic differences are apparent. If, on the other hand, increased density did not alter the growth pattern and genetic differences are observed, the latter hypothesis would be supported. Data available on growth in the present study and biomass in 1977 (Gunderson and Sample, 1980) will 
provide comparative data for future studies as the stocks of Sebastes alutus and presumably S. diploproa are allowed to recover.

Acknowledgements. This work was conducted while the senior author held a NOAA Resident Research Associateship from the National Research Council; this support is gratefully acknowledged. Dr. M. L. Hayes provided advice and encouragement during the course of the study. We thank Dr. D. R. Gunderson, Mr. S. J. Westrheim, and Mr. T. A. Dark for helpful comments on the manuscript. Joan Neuman typed the final copy of the manuscript.

\section{LITERATURE CITED}

Ahlstrom, E. H. (1961). Distribution and relative abundance of rockfish (Sebastodes spp.) larvae off California and Baja California. Rapp. P.-v. Réun. Cons. perm. int. Explor. Mer 150: 169-176

Alverson, D. L., Pruter, A. T., Ronholt, L. L. (1964). A study of demersal fishes and fisheries of the northeastern Pacific Ocean. H. R. MacMillan Lecture Series on Fisheries, Inst. of Fisheries, University of British Columbia

Alverson, D. L, Westrheim, S. J. (1961). A review of the taxonomy and biology of the Pacific ocean perch and its fishery. Rapp. P.-v. Réun. Cons. perm. int. Explor. Mer 150: $12-27$

Bakun, A. (1975). Daily and weekly upwelling indices, west coast of North America, 1967-1973. NOAA Tech. Rept., NMFS Spec. Sci. Rep., Fisheries 693: 1-114

Beverton, R. J. H., Holt, S. J. (1959). A review of the lifespan and mortality rates of fish in nature, and their relation to growth and other physiological characteristics. In: Wolstenholme, G. E. W., O'Connor, M., (eds) CIBA Found. Colloquia on ageing, Vol. 5, The lifespan of animals. Little, Brown, and Co. Boston, pp. 142-177

Boehlert, G. W. (1977). Timing of the surface-to-benthic migration in juvenile rockfish, Sebastes diploproa, off southern California. Fish. Bull., U.S. 75: 887-890

Boehlert, G. W. (1980). Size composition, age composition, and growth of the canary rockfish (Sebastes pinniger) and the splitnose rockfish (S. diploproa) from the 1977 Rockfish Survey. Mar. Fish. Rev. 42: 55-60

Boehlert, G. W. (unpublished). Growth of prejuvenile splitnose rockfish, Sebastes diploproa, from the southern California bight, with comments on the season of birth

Carlson, H. R., Haight, R. E. (1972). Evidence for a homesite and homing of adult yellowtail rockfish, Sebastes flavidus. J. Fish. Res. Bd Can. 29: 1011-1014

Chadwick, E. M. P. (1976). A comparsion of growth and abundance for tidal pool fishes in California and British Columbia. J. Fish. Biol. 8: 27-34

Charnov, E. L., Schaffer, W. M. (1973). Life history consequences of natural selection: Cole's result revisited. Am. Nat. 107: 791-793

Chingin, J., Halminski, S. S. (1974). Temperature, salinity, oxygen, and phosphate in waters off the United States. Vol. III. Eastern North Pacific. Key to Oceanog. Documents. No. 2, $260 \mathrm{pp}$

Doudoroff, P., Shumway, D. L. (1970). Dissolved oxygen requirements for freshwater fishes. FAO Fish. Tech. Pap. No. 86

Geisser, S., Eddy, W. F. (1979). A predictive approach to model selection. J. Am. Stat. Ass. 74: 153-160
Gunderson, D. R. (1972). Evidence that Pacific ocean perch (Sebastes alutus) in Queen Charlotte Sound form aggregations that have different biological characteristics. J. Fish. Res. Bd Can. 29: 1061-1070

Gunderson, D. R. (1977). Population biology of Pacific ocean perch, Sebastes alutus, stocks in the Washington-Queen Charlotte Sound region, and their response to fishing. Fish. Bull., U.S. 75: 369-403

Gunderson, D. R., Callahan, P., Goiney, B. (1980). Maturation and fecundity of four species of Sebastes. Mar. Fish. Rev. 42: 71-76

Gunderson, D. R., Sample, T. (1980). Distribution and Abundance of Rockfish off Washington, Oregon and California during 1977. Mar. Fish. Rev.: in press

Hart, J. L. (1973). Pacific Fishes of Canada Bull. Fish. Res. Bd Can. 180: 1-740

Heimann, R. F. G. (1963). Trawling in the Monterey Bay area, with special reference to catch composition. Calif. Fish Game 49: 152-173

Jones, R. (1973). Density dependent regulation of the numbers of cod and haddock. Rapp. P.-v. Réun. Cons. perm. int. Explor. Mer 164: 156-173

Kappenman, R. (in preparation). A method for growth curve comparison

Kelly, G. F., Wolf, R. S. (1959). Age and growth of the redfish (Sebastes marinus) in the Gulf of Maine. Fish. Bull. U.S. 60: $1-31$

Kimura, D. K., Mandapat, R. R., Oxford, S. L. (1979). Method, validity, and variability in the age determination of yellowtail rockfish (Sebastes flavidus) using otoliths. J. Fish. Res. Bd Can. 36: 377-383

Leggett, W. C., Carscadden, J. E. (1978). Latitudinal variation in reproductive characteristics of American shad (Alosa sapidissima): evidence for population specific life history strategies in fish. J. Fish. Res. Bd Can. 35: 1469-1478

Love, M. (1977). Aspects of the life history of the olive rockfish, Sebastes serranoides. Ph. D. thesis, University of California at Santa Barbara

Love, M. S., Larson, R. J. (1978). Geographic variation in the occurrence of tympanic spines and possible genetic differentiation in the kelp rockfish (Sebastes atrovirens). Copeia 1978: 53-59

MacGregor, J. S. (1970). Fecundity, multiple spawning, and description of the gonads in Sebastodes. Spec. scient. Rep., U.S. Fish Wildl. Serv. Fisheries 596: 1-12

Maraldo, D. D., MacCrimmon, H. R. (1979). Comparison of ageing methods and growth rates for largemouth bass, Micropterus salmoides Lacepede, from northern latitudes. Env. Biol. Fishes 4: 263-271

Margetts, A. R., Holt, S. J. (1948). The effect of the 1939-45 war on the English North Sea trawl fisheries. Rapp. P.-v. Réun. Cons. perm. int. Explor. Mer 122: 26-46

Miller, D. J., Gotshall, D. (1965). Ocean sportfish catch and effort from Oregon to Pt. Arguello, California. Calif. Fish Game Fish. Bull. 130: 1-135

Moser, H. G. (1967). Reproduction and development of Sebastodes paucispinis and comparison with other rockfishes off southern California. Copeia 1967: 773-797

Moser, H. G., Ahlstrom, E. H. (1978). Larvae and pelagic juveniles of blackgill rockfish, Sebastes melanostomus, taken in midwater trawls off southern California and Baja California. J. Fish. Res. Bd Can. 35: 981-996

Murphy, G. I. (1968). Pattern in life history and the environment. Am. Nat. 102: 391-403

Nitsos, R. J., Reed, P. H., (1965). The animal food fishery in California, 1961-1962. Calif. Fish. Game 51: 16-27

Parrish, R. H. (1977). Environmental-dependent recruitment 
models and exploitation simulations of the California current stock of Pacific mackerel, Scomber japonicus. Ph.D. thesis, Oregon State University

Phillips, J. B. (1964). Life history studies on ten species of rockfish (genus Sebastodes). Calif. Fish Game, Fish. Bull. 126: $1-70$

Schaffer, W. M., Elson, R. F. (1975). The adaptive significance of variations in life history among local populations of Atlantic salmon in North America. Ecology 56: 577-590

Six, L. D., Horton, H. F. (1977). Analysis of age determination methods for yellowtail rockfish, canary rockfish, and black rockfish off Oregon. Fish. Bull. U.S. 75: 405-414

Snytko, V. A., Fedorov, V. V. (1974). New data in the distribution of scorpaenid fishes of the subfamily Sebastinae and notes on their biology. J. Ichthyol. 14: 811-818

Stewart, N. E., Shumway, D. L., Doudoroff, P. (1967). Influence of oxygen concentration on the growth of juvenile largemouth bass. J. Fish. Res. Bd Can. 24: 475-494

Tsuyuki. H., Roberts, E., Lowes, R. H., Hadaway, W., Westrheim, S. J. (1968). Contribution of protein electrophoresis to rockfish (Scorpaenidae) systematics. J. Fish. Res. Bd Can. 25: 2477-2501
Westrheim, S. J. (1973). Age determination and growth of Pacific ocean perch (Sebastes alutus) in the northeast Pacific Ocean. J. Fish. Res. Bd Can. 30: 235-247

Westrheim, S. J. (1975). Reproduction, maturation, and identification of larvae of some Sebastes (Scorpaenidae) species in the northeast Pacific Ocean. J. Fish. Res. Bd Can. 32: 2399-2411

Westrheim, S. J., Harling, W. R. (1973). Report on the 1972 comparison of Pacific ocean perch otolith and scale interpretations. Fish. Res. Bd Can. Manuscript Rep. Ser. 1259

Westrheim, S. J., Harling, W. R. (1975). Age-length relationships for 26 scorpaenids in the northeast Pacific Ocean. Fish. Mar. Serv. (Can.)., Res. Dev. Dir., Tech. Rep. 565: $1-12$

Wishard, L., Utter, F., Gunderson, D. R. (1980). Stock separation of five rockfish species using naturally occurring biochemical genetic markers. Mar. Fish. Rev. 42:61-70

Withler, I. L. (1966). Variability in life history characteristics of steelhead trout (Salmo gairdneri) along the Pacific coast of North America. J. Fish. Res. Bd Can. 23: 365-394

This paper was presented by Dr. N. D. Holland; it was accepted for printing on April 10, 1980 